\title{
Lamin Protein Gene Expression in Childhood Acute Lymphoblastic Leukemia
}

\author{
Ayse OZKAN, Ibrahim BAYRAM, Gulay SEZGIN, Can ACIPAYAM, Serhan KUPELI, Atila TANYELI \\ Cukurova University Faculty of Medicine, Department of Pediatric Oncology \\ and Pediatric Bone Marrow Transplantation Unit, Adana,TURKEY
}

\begin{abstract}
Acute lymphoblastic leukemia (ALL) is the most common type of cancer in children. The identification of prognostic factors has become essential in design and analysis of modern therapeutic trials. The aim of this study is to present the expression patterns of lamin $\mathrm{A} / \mathrm{C}$, lamin B1 and B2 and their prognostic value in childhood acute lymphoblastic leukemias, which are thought to be related with cell proliferation and apoptosis. The study was carried out between January 2008 and March 2014 at the Cukurova University Faculty of Medicine, Division of Pediatric Oncology and sixty-four patients diagnosed with ALL and 35 control cases were included in the study. Real Time-Polymerase Chain Reaction (RT-PCR) method was used to detect lamin AVC, lamin B1 and lamin B2 protein expression at the time of the diagnosis and at the end of the induction treatment. At the time of the diagnosis, lamin $\mathrm{B} 1$ protein gene expression was lower in ALL patients when compared to the control group $(p=0.001)$. When lamin gene expression levels at the time of diagnosis and after induction therapy were compared, the lamin A/C and B2 gene expressions were significantly lower after the administration of induction chemotherapy (both values $p=0.0001)$. The decrease in lamin B1 gene expression was not statistically significant $(p=$ 0.403). When the lamin expression levels in the control group were compared with the levels after induction chemotheraphy, lamin expressions were found to be significantly lower (all $p$ values 0.0001). In childhood ALL, lamin B1 protein gene expression could be used as a diagnostic marker, while decrease in the lamin A/C and B2 protein gene expressions after induction could be used as a marker for response to therapy. Our study is the first to show in lamin protein gene expression relationship with diagnosis and prognosis in ALL in literature. Comprehensive multicenter studies are needed with a larger cohort of patients to reach more reliable results.
\end{abstract}

Keywords: Acute lymphoblastic leukemia, Childhood, Lamin proteins

\section{ÖZET}

\section{Çocukluk Çağı Akut Lenfoblastik Lösemilerinde Lamin Protein Gen Ekspresyonu}

Akut lenfoblastik lösemi (ALL), çocuklarda en sık görülen kanserdir. Prognostik faktörlerin tanımlanması, modern tedavi denemelerinin tasarımı ve analizi için önemlidir. Bu çalışmanın amacı çocukluk çağı ALL'lerinde lamin A/C, lamin B1 ve lamin B2 proteinlerinin gen ekspresyon durumunun saptanması ve prognoz ile olan ilişkilerinin değerlendirilmesidir. Akut lenfoblastik lösemi tanısı alan 64 hasta ve 35 kontrol olgu çalışmaya dahil edildi. Tanı anında ve indüksiyon kemoterapisi bitiminde lamin A/C, lamin B1 ve lamin B2 protein gen ekspresyonları Real Time PCR yöntemi ile çalışılı.ALL hastalarımızda, tanı anında bakılan lamin B1 protein gen ekspresyonu kontrol grubuna göre belirgin olarak düşük bulundu $(p=0,001)$. Tanı anındaki lamin protein gen ekspresyonu düzeyleri ile indüksiyon kemoterapisi sonrasında bakılan lamin protein gen ekspresyonu düzeyleri karşılaştııldığında; indüksiyon kemoterapisi verildikten sonra lamin A/C ve B2 protein gen ekspresyon düzeylerinin anlamlı olarak azaldığı görülmüştür (her iki değeri $p=0.0001$ ). Lamin B1 protein gen ekspresyon düzeyindeki azalmanın ise anlamlı olmadığı görülmüştür (p:0,403). Kontrol grubu ile indüksiyon kemoterapisi sonrasındaki lamin düzeyleri karşılaştııılığında ise tüm lamin protein gen ekspresyon düzeylerinde anlamlı bir azalma saptanmıştır (tüm p değeri 0.0001 idi). Çocukluk çağı akut lenfoblastik lösemilerinde, lamin B1 protein gen ekspresyonu, tanısal bir belirteç olarak, lamin B2 protein gen ekspresyonu ise prognostik bir belirteç olarak kullanilabilir.

Anahtar Kelimeler: Akut lenfoblastik lösemi, Çocukluk çağı, Lamin proteinleri

ORCIDS: Ayse Ozkan: 0000-0003-1181-8169 Ibrahim Bayram: 0000-0003-0330-4766 Can Acipayam: 0000-0002-6379-224X
Serhan Kupeli: 0000-0001-7271-1803
Gulay Sezgin: 0000-0003-2396-5692 Atila Tanyeli: 0000-0001-9526-2035 


\section{INTRODUCTION}

Acute lymphoblastic leukemia (ALL) is the most common type of cancer in children, accounting for one-fourth of all childhood cancers and $72 \%$ of all childhood leukemias. ${ }^{1}$ ALL is fatal unless treated, and certain clinical and laboratory parameters at the initial diagnosis may predict disease prognosis. Determining the mechanisms of leukemogenesis in patients may allow the introduction of targeted therapies. ${ }^{1}$

Blastic cells in leukemia show a monoclonal proliferation through mitosis. The cell is composed of cytoplasm and nucleus, and the nuclear envelope formed by the inner and outer membranes of the nucleus is surrounded on both sides by intermediate filaments. The filaments that surround the outer membrane are disorganized, while the filaments that surround the inner membrane as a fibrous network are arranged in regular order, and this fibrous network is known as the nuclear lamina. This nuclear lamina provides mechanical support to the nucleus beneath the inner membrane of the nucleus but also regulates such important cellular processes as DNA replication and cellular division. The nuclear lamina is made up of two components: lamins and nuclear lamin-associated membrane proteins. ${ }^{2}$

Lamins are type- $\mathrm{V}$ intermediate filaments, and there are three genes that encode lamin proteins in human somatic cells. Type-A lamins (A and C) are a product of the LMNA gene. Type-B lamins are encoded by LMNB1 (lamin B1) and LMNB2 (lamin B2) genes. ${ }^{3-5}$ Type-B lamins are required for cell survival. ${ }^{6}$ Lamin B1 and B2 are expressed by numerous cells. However, lamin B2 is found in a higher number of cells than lamin B1. Type-A lamin is expressed only in differentiated cells. ${ }^{7}$ There are studies into the use of lamins as a marker in the early diagnosis of cancer, in the evaluation of characteristics and in predicting the survival of patients. ${ }^{8}$ Studies that analyze the relationship between lamin protein expression and cancer have mostly been performed on solid tumors, while studies of leukemia in this regard are very limited. ${ }^{9-10}$

The present study aims to evaluate the lamin protein gene expression status in cases of childhood acute lymphoblastic leukemia, as well as its relationship to prognosis.

\section{PATIENTS AND METHODS}

A total of 73 patients were diagnosed with ALL, at the Division of Pediatric Oncology, Cukurova University Faculty of Medicine, between January 2008 and March 2014. In this study, patients with ALL of the L3 subtype were excluded $(n=5)$, while 64 patients who underwent ribonucleic acid (RNA) isolation at the time of diagnosis were included. 35 children who were admitted to the Department of Pediatrics General Outpatient Clinic for a regular follow-up, who did not have leukemia and who had normal physical examination findings and a normal hematological status based on a complete blood count and a peripheral blood smear examination, were included as the control group. Informed consent was obtained from the patients, control subjects and/or legal guardians before enrollment in the study, which was conducted in accordance with local institutional regulations.

Cell extraction was performed from blood samples using standard methods and collected in $3 \mathrm{ml}$ ethylene diamine tetra aceticacid (EDTA) tubes at the time of diagnosis and after induction therapy in patients with ALL. The RNA was isolated from the cells, and the isolated RNA samples were stored in a deep freeze at $-85^{\circ} \mathrm{C}$ until analysis. The RNA from the samples was then transcribed into complementary deoxyribonucleic acid (cDNA) and stored at $-20 \mathrm{oC}$. A RT-PCR method was used to detect lamin $\mathrm{A} / \mathrm{C}$, lamin $\mathrm{B} 1$ and lamin $\mathrm{B} 2$ protein gene expressions at the time of the diagnosis and the end of the induction treatment. This study was conduced using a Light Cycler (Roche Applied Science).

\section{Analysis}

Housekeeping Genes and Target Genes were analyzed through an "Advanced Relative Quantification" using LC 480 Software at a wavelength suitable for the design.

\section{Statistical Methods}

All statistical analyses were carried out using the SPSS v16.0 (statistical package for social sciences) software package. A Pearson's correlation test and Kaplan-Meier survival analysis were performed to evaluate the garnered data, while a one-way analysis 
Table 1. Lamin protein gene expression results of the control group and the ALL patients at the time of diagnosis and after induction therapy

\begin{tabular}{|c|c|c|c|c|c|c|}
\hline & $\begin{array}{l}\text { ALL at the time } \\
\text { of diagnosis }(n=64)\end{array}$ & $\begin{array}{l}\text { ALL after induction } \\
\text { therapy }(n=30)\end{array}$ & $\begin{array}{l}\text { Control group } \\
(n=35)\end{array}$ & $\mathrm{Pa}$ & $\mathrm{Pb}$ & Pc \\
\hline \multicolumn{7}{|l|}{ Lamin AVC } \\
\hline$($ mean $\pm S D)$ & $3.33 \pm 5.84$ & $0.36 \pm 0.23$ & $2.42 \pm 1.51$ & 0.0001 & 0.096 & 0.0001 \\
\hline (min-max) & (0.07-35.26) & (0.08-1.09) & (0.70-6.02) & & & \\
\hline \multicolumn{7}{|l|}{ Lamin B1 } \\
\hline$($ mean $\pm S D)$ & $1.98 \pm 1.37$ & $1.44 \pm 1.11$ & $3.28 \pm 2.30$ & 0.403 & 0.001 & 0.0001 \\
\hline (min-max) & $(0.46-6.82)$ & $(0.47-5.98)$ & $(0.00-9.78)$ & & & \\
\hline \multicolumn{7}{|l|}{ Lamin B2 } \\
\hline$($ mean $\pm S D)$ & $7.45 \pm 11.78$ & $1.27 \pm 1.36$ & $5.16 \pm 4.32$ & 0.0001 & 0.239 & 0.0001 \\
\hline (min-max) & (0.11-67.18) & (0.22-5.28) & (0.84-18.77) & & & \\
\hline
\end{tabular}

of variance (ANOVA) and a Mann-Whitney U-test were performed to compare the groups. A p-value of $<0.05$ was considered statistically significant.

\section{RESULTS}

Of the 64 cases diagnosed with acute lymphoblastic leukemia included in this study, $30(46.9 \%)$ had ALL L1, and 34 (53.1\%) had an ALL L2 morphology. In the ALL group, 41 patients $(64.1 \%)$ were male and $23(35.9 \%)$ were female, corresponding to a male-female ratio of 1.78. In the control group, 22 subjects (62.9\%) were male and $13(37.1 \%)$ were female, corresponding to a male-female ratio of 1.69 . The mean age of the ALL patients was $79.7 \pm 53.9$ months (7-213), while the mean age in the control group was $84.7 \pm 60.6$ (12-204) months, and the ALL and control groups were matched in terms of gender and age.

The gene expression of lamin proteins was re-studied in 64 patients $(87.7 \%)$ at the time of diagnosis and in 30 patients $(41.1 \%)$ after induction therapy. The lamin A/C, lamin B1 and lamin B2 protein expression results of the ALL patients and the control group are shown in Table 1.

A comparison of the results of patients with ALL and patients in the control group reveals that the lamin $\mathrm{A} / \mathrm{C}$ and $\mathrm{B} 2$ gene expressions in the ALL group are higher (not statistically significant, $\mathrm{p}=0.096$ and $\mathrm{p}=$ 0.239 , respectively), whereas the lamin B1 gene expression was significantly lower $(\mathrm{p}=0.001)$ at the time of diagnosis.

When lamin gene expression levels at the time of diagnosis and after induction therapy were compared, the lamin A/C and B2 gene expressions were significantly lower after the administration of induction chemotherapy (both values $\mathrm{p}=0.0001$ ). The decrease in lamin B1 gene expression was not statistically significant $(\mathrm{p}=0.403)$. When the lamin expression levels in the control group were compared with the levels after induction chemotheraphy, lamin expressions were found to be significantly lower (all p values 0.0001) (Table 1).

In the comparison of lamin expression levels at the time of diagnosis and the patient characteristics, the lamin $\mathrm{A} / \mathrm{C}$ and $\mathrm{B} 2$ gene expressions at the time of diagnosis were significantly higher in the non-survivors than in the survivors $(\mathrm{p}=0.036$ and $\mathrm{p}=0.005$, respectively). However, lamin protein gene expressions were not significantly different between the female and male genders, between the age groups (patients aged 2-6 years, patients below the age of 2 and those aged 6 years and over), between patients with and without relapse, and patients with and without central nervous system involvement ( $p>$ 0.05) (Table 2). 
International Journal of Hematology and Oncology

\begin{tabular}{|c|c|c|c|c|c|c|c|c|}
\hline & & $\mathbf{n}$ & Lamin A/C & $\mathbf{P}$ & Lamin B1 & $\mathbf{P}$ & Lamin B2 & $\mathbf{P}$ \\
\hline \multirow[t]{2}{*}{ Female } & $($ mean $\pm S D)$ & 23 & $3.87 \pm 5.50$ & 0.57 & $1.66 \pm 1.24$ & 0.15 & $9.36 \pm 15.20$ & 0.33 \\
\hline & $(\min -\max )$ & & $0.07-21.26$ & & $0.46-5.31$ & & $0.93-67.18$ & \\
\hline \multirow[t]{2}{*}{ Male } & $($ mean $\pm S D)$ & 41 & $3.02 \pm 6.07$ & & $2.17 \pm 1.42$ & & $6.37 \pm 9.40$ & \\
\hline & (min-max) & & $0.21-35.26$ & & $0.48-6.82$ & & $0.11-44.32$ & \\
\hline \multirow{3}{*}{$\begin{array}{l}\text { Aged below } \\
2 \text { years }\end{array}$} & $($ mean $\pm S D)$ & 8 & $5.75 \pm 11.9$ & & $1.53 \pm 1.28$ & & $7.29 \pm 5.63$ & \\
\hline & & & & & & & & \\
\hline & (min-max) & & $0.37-35.26$ & & $0.46-4.20$ & & $0.93-14.72$ & \\
\hline \multirow[t]{2}{*}{ 2-6 years } & $($ mean $\pm S D)$ & 28 & $2.10 \pm 2.19$ & 0.12 & $1.70 \pm 0.84$ & 0.66 & $6.03 \pm 12.61$ & 0.78 \\
\hline & $(\min -\max )$ & & $0.07-8.57$ & & $0.49-3.13$ & & $0.12-67.18$ & \\
\hline \multirow[t]{2}{*}{6 years above } & $($ mean $\pm S D)$ & 28 & $3.85 \pm 5.83$ & 0.14 & $2.39 \pm 1.71$ & 0.062 & $8.92 \pm 12.35$ & 0.39 \\
\hline & (min-max) & & $0.21-21.26$ & & $0.66-6.82$ & & $0.11-44.32$ & \\
\hline \multirow[t]{2}{*}{ With relapse } & $($ mean $\pm S D)$ & 15 & $3.61 \pm 4.74$ & 0.83 & $2.16 \pm 0.97$ & 0.56 & $9.09 \pm 16.57$ & 0.54 \\
\hline & (min-max) & & $0.40-19.03$ & & $0.92-4.76$ & & $0.12-67.18$ & \\
\hline \multirow[t]{2}{*}{ Without relapse } & $($ mean $\pm S D)$ & 49 & $3.24 \pm 6.17$ & & $1.92 \pm 1.47$ & & $6.95 \pm 10.05$ & \\
\hline & (min-max) & & $0.07-35.26$ & & $0.46-6.82$ & & $0.11-44.32$ & \\
\hline \multirow[t]{2}{*}{ Non-survivor } & $($ mean $\pm S D)$ & 13 & $6.26 \pm 7.82$ & 0.036 & $2.34 \pm 1.24$ & 0.17 & $12.24 \pm 13.8$ & 0.005 \\
\hline & (min-max) & & $0.23-21.26$ & & $0.66-4.76$ & & $1.09-44.32$ & \\
\hline \multirow[t]{2}{*}{ Survivor } & $($ mean $\pm S D)$ & 48 & $2.41 \pm 5.09$ & & $1.78 \pm 1.33$ & & $4.59 \pm 6.33$ & \\
\hline & $(\min -\max )$ & & $0.07-35.26$ & & $0.46-6.82$ & & $0.11-35.51$ & \\
\hline \multirow[t]{2}{*}{ Out of follow-up } & $($ mean $\pm S D)$ & 3 & $5.29 \pm 3.79$ & & $3.70 \pm 1.39$ & & $3.50 \pm 31.68$ & \\
\hline & (min-max) & & $2.14-9.51$ & & $2.77-5.31$ & & $5.06-67.18$ & \\
\hline \multirow[t]{2}{*}{ CNS relapse $(+)$} & (mean $\pm S D)$ & 12 & $3.62 \pm 5.30$ & 0.84 & $2.12 \pm 1.05$ & 0.69 & $4.72 \pm 3.94$ & 0.37 \\
\hline & (min-max) & & $0.40-19.03$ & & $0.92-4.76$ & & $0.12-11.96$ & \\
\hline \multirow[t]{2}{*}{ CNS relapse (-) } & $($ mean $\pm S D)$ & 52 & $3.26 \pm 6.00$ & & $1.95 \pm 1.44$ & & $8.08 \pm 12.89$ & \\
\hline & (min-max) & & $0.07-35.26$ & & $0.46-6.82$ & & $0.11-67.18$ & \\
\hline
\end{tabular}

On the other hand, the lamin B1 gene expression was significantly higher in patients with a white blood cell count between $50.000-100.000 / \mathrm{mm}^{3}$ than in patients with a white blood cell count below 20.000/ $\mathrm{mm} 3(\mathrm{p}=0.009)$. The gene expressions of both the lamin B1 and lamin B2 gene expressions were significantly higher in patients with a white blood cell count higher than $50.000 / \mathrm{mm}^{3}$ when compared to patients with a white blood cell count of below $50.000 / \mathrm{mm}^{3}(\mathrm{p}=0.008$ and $\mathrm{p}=0.024$, respectively). In addition, the lamin $\mathrm{B} 1$ gene expression was significantly higher in patients with a B-cell ALL phe- notype than in patients with a T-cell ALL phenotype $(p=0.004)$. In contrast, no significant difference was identified in the lamin gene expression results in BFM risk groups between patients with and without neutropenia regarding other parameters of white blood cells ( $p>0.05$ ) (Table 3 ).

Finally, in lamin $B 1(p=0.008$ and $p=0.027$, respectively) and lamin B2 (p=0.024 and $\mathrm{p}=0.012$, respectively) gene expression levels were significantly higher in patients with hepatomegaly than in patients without hepatomegaly, as well as in patients with splenomegaly than in patients without 
International Journal of Hematology and Oncology

\begin{tabular}{|c|c|c|c|c|c|c|c|c|}
\hline & & $\mathbf{n}$ & Lamin A/C & $\mathbf{P}$ & Lamin B1 & $\mathbf{P}$ & Lamin B2 & $\mathbf{P}$ \\
\hline \multirow[t]{2}{*}{ SRG } & $($ mean $\pm S D)$ & 15 & $3.84 \pm 8.79$ & & $1.80 \pm 0.81$ & & $3.50 \pm 3.42$ & \\
\hline & (min-max) & & $0.37-35.26$ & & $0.61-3.12$ & & $0.12-11.3$ & \\
\hline \multirow[t]{2}{*}{ MRG } & $($ mean $\pm S D)$ & 38 & $2.85 \pm 4.24$ & 0.58 & $2.14 \pm 1.53$ & 0.42 & $8.96 \pm 13.37$ & 0.12 \\
\hline & (min-max) & & $0.07-19.03$ & & $0.46-6.82$ & & $0.11-67.18$ & \\
\hline \multirow[t]{2}{*}{$\mathrm{HRG}$} & $($ mean $\pm S D)$ & 11 & $4.26 \pm 6.15$ & 0.89 & $1.70 \pm 1.41$ & 0.81 & $7.61 \pm 12.85$ & 0.24 \\
\hline & (min-max) & & $0.21-21.26$ & & $0.49-4.20$ & & $0.99-44.32$ & \\
\hline \multirow[t]{2}{*}{ *WBC <20000 } & $($ mean $\pm S D)$ & 38 & $3.65 \pm 6.68$ & & $1.77 \pm 1.07$ & & $5.94 \pm 12.20$ & \\
\hline & (min-max) & & $0.21-35.26$ & & $0.49-5.31$ & & $0.11-64.18$ & \\
\hline \multicolumn{9}{|l|}{ WBC } \\
\hline \multirow[t]{2}{*}{$20000-50000$} & $($ mean $\pm S D)$ & 10 & $4.25 \pm 6.49$ & 0.8 & $1.46 \pm 0.68$ & 0.39 & $5.63 \pm 4.86$ & 0.93 \\
\hline & $(\min -\max )$ & & $0.07-21.26$ & & $0.46-2.77$ & & $1.09-12.50$ & \\
\hline \multirow[t]{2}{*}{ WBC 50000-100000 } & $($ mean $\pm S D)$ & 6 & $2.61 \pm 3.11$ & 0.7 & $3.44 \pm 2.73$ & 0.009 & $13.25 \pm 12.3$ & 0.18 \\
\hline & (min-max) & & $0.21-8.46$ & & $0.48-6.82$ & & $12.39-35.5$ & \\
\hline \multirow[t]{2}{*}{ WBC $>100000$} & $($ mean $\pm S D)$ & 7 & $1.73 \pm 1.91$ & 0.46 & $2.65 \pm 1.46$ & 0.064 & $15.01 \pm 14.6$ & 0.09 \\
\hline & (min-max) & & $0.37-5.70$ & & $0.65-4.20$ & & $1.38-44.32$ & \\
\hline \multirow[t]{2}{*}{ *WBC <20000 } & & 38 & $3,5 \pm 6,6$ & 0.7 & $1,74 \pm 1,08$ & 0.06 & $6,12 \pm 12,11$ & 0.18 \\
\hline & & & $0,21-35,3$ & & $0,46-5,31$ & & $0,11-67,18$ & \\
\hline \multirow[t]{2}{*}{ WBC >20000 } & & 23 & $3,07 \pm 4,77$ & & $2,43 \pm 1,78$ & & $10,38 \pm 11,69$ & \\
\hline & & & $0,07-21,26$ & & $0,48-6,82$ & & $1,09-44,32$ & \\
\hline \multirow[t]{2}{*}{ *WBC <50000 } & & 48 & $3,64 \pm 6,48$ & 0.55 & $1,77 \pm 1,05$ & 0.008 & $6,04 \pm 10,99$ & 0.024 \\
\hline & & & $0,07-35,26$ & & $0,46-5,31$ & & $0,11-67,18$ & \\
\hline \multirow[t]{2}{*}{ WBC >50000 } & & 13 & $2,45 \pm 2,57$ & & $2,98 \pm 2,25$ & & $15,0 \pm 14,67$ & \\
\hline & & & $0,21-8,46$ & & $0,48-6,82$ & & $1,21-44,32$ & \\
\hline \multirow[t]{2}{*}{ *Neutropenia(+) } & $($ mean $\pm S D)$ & 16 & $2.08 \pm 1.70$ & 0.29 & $1.76 \pm 0.85$ & 0.47 & $4.18 \pm 10.72$ & 0.18 \\
\hline & (min-max) & & $0.52-5.70$ & & $0.86-4.08$ & & $0.12-44.32$ & \\
\hline \multirow[t]{2}{*}{ Neutropenia(-) } & $($ mean $\pm S D)$ & 45 & $3.90 \pm 6.82$ & & $2.06 \pm 1.54$ & & $8.88 \pm 12.35$ & \\
\hline & (min-max) & & $0.07-35.26$ & & $0.46-8.82$ & & $0.11-67.18$ & \\
\hline \multirow[t]{2}{*}{ *T-ALL } & $($ mean $\pm S D)$ & 11 & $1.43 \pm 1.30$ & 0.33 & $3.19 \pm 2.07$ & 0.004 & $10.68 \pm 11.25$ & 0.48 \\
\hline & (min-max) & & $0.07-4.17$ & & $1.16-6.82$ & & $0.63-35.51$ & \\
\hline \multirow[t]{2}{*}{ B-ALL (Pre/Pro) } & $($ mean $\pm S D)$ & 43 & $3.21 \pm 5.96$ & & $1.81 \pm 1.1$ & & $7.61 \pm 13.02$ & \\
\hline & (min-max) & & $0.21-35.26$ & & $0.46-5.31$ & & $0.11-67.18$ & \\
\hline
\end{tabular}

splenomegaly. The lamin B2 gene expression was significantly higher in patients without anemia than in patients with anemia $(p=0.009)$. However, this was not deemed to be significant due to the small number of patients in the sample. In contrast to this, no relationship was demonstrated between the lamin gene expression levels and thrombocytopenia and lymphadenopathy (Table 4). 
International Journal of Hematology and Oncology

\begin{tabular}{|c|c|c|c|c|c|c|c|c|}
\hline & & $\mathbf{n}$ & Lamin A/C & $\mathbf{P}$ & Lamin B1 & $\mathbf{P}$ & Lamin B2 & $\mathbf{P}$ \\
\hline \multirow[t]{2}{*}{ *Anemia (+) } & $($ mean $\pm S D)$ & 56 & $3.31 \pm 5.88$ & & $1.97 \pm 1.45$ & & $6.46 \pm 8.80$ & \\
\hline & $(\min -\max )$ & & $0.07-35.26$ & & $0.46-6.82$ & & $0.12-44.3$ & \\
\hline \multirow[t]{2}{*}{ Anemia (-) } & $($ mean $\pm S D)$ & 5 & $4.73 \pm 7.38$ & 0.61 & $2.07 \pm 0.62$ & 0.88 & $20.95 \pm 29.4$ & 0.009 \\
\hline & (min-max) & & $0.22-17.63$ & & $1.39-3.03$ & & $0.11-67.18$ & \\
\hline \multirow{2}{*}{ Thrombocytopenia (+) } & ) $($ mean $\pm S D)$ & 46 & $3.36 \pm 6.37$ & 0.88 & $2.09 \pm 1.55$ & 0.29 & $8.61 \pm 12.91$ & 0.027 \\
\hline & (min-max) & & $0.07-35.26$ & & $0.46-6.82$ & & $0.11-67.18$ & \\
\hline \multirow[t]{2}{*}{ Thrombocytopenia (-) } & $($ mean $\pm S D)$ & 15 & $3.62 \pm 46.8$ & & $1.65 \pm 0.69$ & & $4.70 \pm 8.55$ & \\
\hline & (min-max) & & $0.21-17.68$ & & $0.92-3.16$ & & $0.31-33.82$ & \\
\hline \multirow[t]{2}{*}{ Hepatomegaly (+) } & $($ mean $\pm S D)$ & 33 & $3.26 \pm 4.92$ & 0.90 & $2.40 \pm 1.69$ & 0.008 & $10.68 \pm 14.50$ & 0.024 \\
\hline & (min-max) & & $0.07-21.26$ & & $0.46-6.82$ & & $11-67.18$ & \\
\hline \multirow[t]{2}{*}{ Hepatomegaly (-) } & $($ mean $\pm S D)$ & 31 & $3.44 \pm 6.87$ & & $1.50 \pm 0.68$ & & $3.97 \pm 6.52$ & \\
\hline & (min-max) & & $0.21-35.26$ & & $0.48-3.16$ & & $0.31-33.82$ & \\
\hline \multirow[t]{2}{*}{ Splenomegaly (+) } & $($ mean $\pm S D)$ & 30 & $3.20 \pm 5.04$ & 0.85 & $2.37 \pm 1.79$ & 0.027 & $11.37 \pm 15.0$ & 0.012 \\
\hline & (min-max) & & $0.07-21.26$ & & $0.46-6.82$ & & $0.93-67.18$ & \\
\hline \multirow[t]{2}{*}{ Splenomegaly (-) } & $($ mean $\pm S D)$ & 34 & $3.47 \pm 6.63$ & & $1.60 \pm 0.63$ & & $3.9 .6 \pm 6.45$ & \\
\hline & (min-max) & & $0.21-35.26$ & & $0.48-3.16$ & & $0.11-33.82$ & \\
\hline \multirow[t]{2}{*}{ LAP (+) } & $($ mean $\pm S D)$ & 28 & $4.17 \pm 7.49$ & 0.61 & $1.95 \pm 1.55$ & 0.84 & $7.18 \pm 10.88$ & 0.96 \\
\hline & $(\min -\max )$ & & $0.07-35.26$ & & $0.49-6.82$ & & $0.11-44.32$ & \\
\hline \multirow[t]{2}{*}{ LAP (-) } & $($ mean $\pm S D)$ & 36 & $2.72 \pm 4.32$ & & $1.98 \pm 1.25$ & & $7.72 \pm 12.72$ & \\
\hline & (min-max) & & $0.21-19.03$ & & $0.46-6.68$ & & $0.12-67.18$ & \\
\hline
\end{tabular}

Pearson correlation test performed on the lamin protein gene expression and age, hematoctrit, hemoglobin, white blood cell count, thrombocyte count, urea, creatinine, SGOT, lactic dehydrogenase, uric acid and alkaline phosphatase-level data revealed no significant correlation in any of the parameters and the lamin $\mathrm{A} / \mathrm{C}$ protein gene expression. In contrast, a positive correlation was identified between the lamin B1 protein gene expression and the lamin $B 2$ protein gene expression $(\mathrm{p}=0.001, \mathrm{r}=0.551)$, age $(\mathrm{p}=0.028, \mathrm{r}=0.275)$, white blood cell count $(\mathrm{p}=$ $0.019, r=0.299)$, urea $(\mathrm{p}=0.0001, \mathrm{r}=0.567)$, creatinine $(\mathrm{p}=0.0001, \mathrm{r}=0.649)$, lactic dehydrogenase $(\mathrm{p}=0.0001, \mathrm{r}=0.507)$ and uric acid levels $(\mathrm{p}=0.001$, $\mathrm{r}=0.400$ ). Furthermore, a positive correlation was noted between lamin B2 protein gene expression and hemoglobin $(\mathrm{p}=0.046, \mathrm{r}=0.257)$, creatinine $(\mathrm{p}=0.026, \mathrm{r}=0.285)$ and lactic dehydrogenase levels $(\mathrm{p}=0.014, \mathrm{r}=0.309)$.

The lamin $\mathrm{A} / \mathrm{C}$, B1 and $\mathrm{B} 2$ protein gene expressions were compared to the control group, and the effects of each expression level on overall survival were investigated. Forty-three cases had lamin A/C protein gene expression below the mean of the control group and twenty-one cases had above. For lamin B1 fifty-four cases had gene expression below the mean of the control and seven cases had above. Lamin B2 protein gene expression was lower than the mean of the control in forty-four patients and above in twenty patients. ALL patients with lower lamin B2 protein gene expression had better sur- 

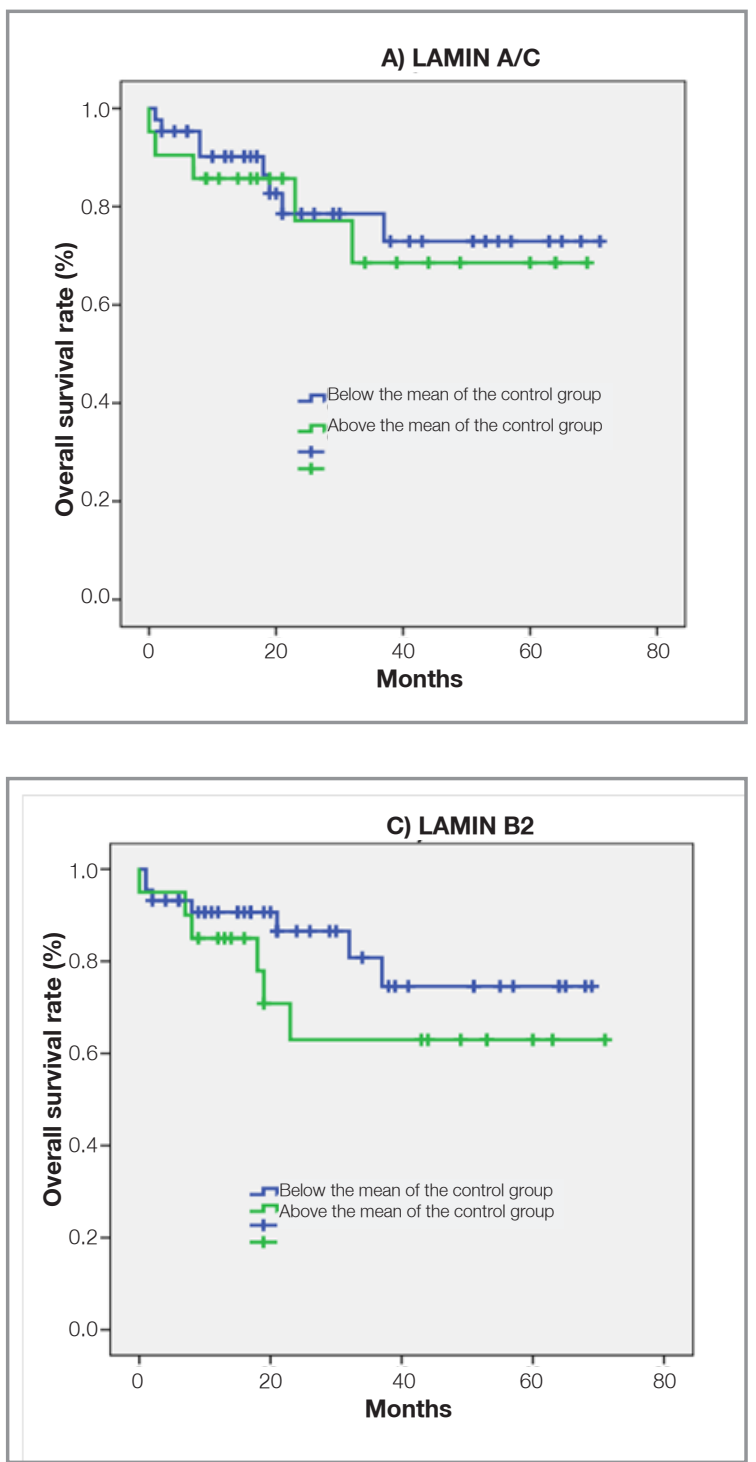

vival outcomes but the results were not statistically significant $(\mathrm{p}>0.05)$. Patients with lower lamin B2 protein gene expression had an $82.5 \%$ three-year overall survival and $75 \%$ five-year overall survival rate. Patients with higher lamin B2 protein gene expression had a $65 \%$ three- and five-year overall survival (Figure 1).

\section{DISCUSSION}

In recent years, studies in developed countries have reported up to an $85 \%$ five-year overall survival rate in patients with ALL. ${ }^{11}$ Modern treatment protocols classify patients as low, standard and high-risk depending on their risk factors, and the purpose of

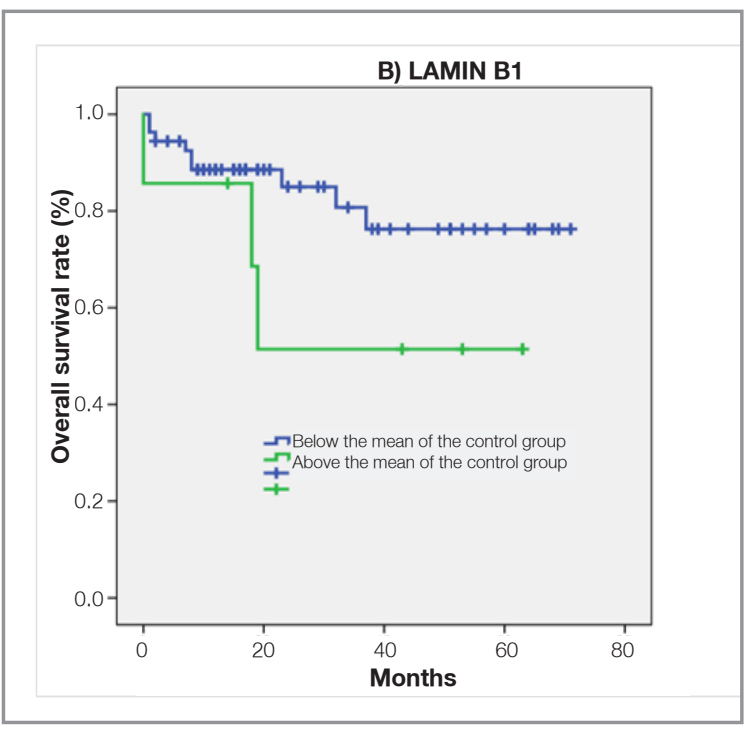

Figure 1. Kaplan-Meier estimations of overall survivals for the Lamin A/C, B1 and B2 protein gene expressions for two groups; below and above the mean of the control group. (A) Effects of lamin $A / C$ protein gene expressions on overall survival. Log rank test was $p=0.76$. (B) Effects of lamin B1 protein gene expressions on overall survival. Log rank test was $\mathrm{p}=0.15$. (C) Effects of lamin B2 protein gene expressions on overall survival. Log rank test was $p=0.29$.

this classification is to identify patients who require intense therapy to the patients in whom a relapse is expected, and to avoid late-term side-effects in patients in the low-risk group. A relapse may sometimes occur in patients with good prognostic factors. $^{12}$

Lamin proteins play a role in the cellular processes associated with tumor progressions, such as nuclear architecture, control of gene expression, apoptosis, chromatin organization and dissociation. ${ }^{13}$ Lamins are often multifunctional proteins that are localized or abnormally expressed in the tumor. ${ }^{8}$

In the study by Kaufmann et al., a type-A lamin gene expression was found to be decreased by $80 \%$ in a series of patients with small-cell lung cancer 
and increased or similar in a series of patients with non-small-cell lung cancer. ${ }^{14}$ Similarly, Broers et al. demonstrated a decrease particularly in type A, and to a lesser extent, in type B lamins in patients with primary lung carcinoma. ${ }^{15}$ Both type A and type B lamin expressions were found to be decreased or below detectable limits in patients with colon carcinoma, adenoma and primary gastric cancer. ${ }^{16}$

Tilli et al. demonstrated an increased expression of lamin $\mathrm{A} / \mathrm{C}$ in cutaneous cell carcinoma than in normal skin, and in the same study, in contrast to the previous finding, they reported rapid tumor progression in cases with basal cell carcinoma without lamin A expression and a slower tumor progression in patients without lamin $\mathrm{C}$ expression. ${ }^{17}$

As can be understood from the few studies reported here, lamin protein gene expression pattern is more complicated than would be expected. In the present study, lamin $\mathrm{A} / \mathrm{C}$ and lamin $\mathrm{B} 2$ protein gene expressions at the time of diagnosis were higher in patients with ALL than in the control subjects; however, the difference was not statistically significant $(\mathrm{p}=0.06$ and $\mathrm{p}=0.239$ ). The lamin $\mathrm{B} 1$ protein gene expression was considerably lower than in the control group $(\mathrm{p}=0.001)$.

In our study, a significant decrease was noted in the lamin $\mathrm{A} / \mathrm{C}$ and lamin $\mathrm{B} 2$ protein gene expression in ALL patients following induction chemotherapy ( $p=0.0001$ and $p=0.0001$, respectively). Although the lamin B1 protein gene expression at the time of diagnosis decreased after the induction phase of chemotherapy, the difference was not statistically significant $(p=0.403)$. All of the lamin protein gene expressions studied in patients with ALL after the induction phase of chemotherapy were significantly lower than in the control group $(\mathrm{p}=0.0001)$, which can be attributed to a decrease in leukemic cell proliferation as a result of the administered therapy. There was an approximately 9-10-fold decrease in lamin $\mathrm{A} / \mathrm{C}$ protein gene expression and an approximately 5-6-fold decrease in lamin B2 protein gene expression after chemotherapy when compared to the control group.

After the discovery of lamin proteins, research demonstrated that lamin subtypes are not expressed by all tissues and cell types, although type-A lamins, in particular, are inversely correlated with tumor proliferation, and so are also referred to as statins. 18
Proliferative cells normally lack type-A lamin expression, although many neoplastic tissues have demonstrated a remarkable type-A lamin expression. In contrast, non-proliferative cells may lack lamin expression. ${ }^{18}$

Similar to this, although patients with ALL in the present study showed lamin $\mathrm{A} / \mathrm{C}$ gene expression at the time of diagnosis, a significant decrease was witnessed in lamin $\mathrm{A} / \mathrm{C}$ protein gene expression with the decrease in the proliferation of leukemic cells after induction therapy $(\mathrm{p}=0.0001)$.

Lamin proteins could be used to differentiate between various tissue and tumors and tumor subtypes. In general, type-A lamins are associated with undifferentiated and non-proliferative cells and tissues.18 However, type-A lamins may exhibit different expression patterns in various cancer types, depending on the cancer subtype, aggressiveness, proliferative capacity and differentiation degree. ${ }^{17}$

Skvortsov et al. reported that lamin A is a useful marker in the grading of prostate cancers and in predicting prognosis. ${ }^{19}$ In the study by Willis et al. increased expression of type-A lamins in colorectal cancer tissue was found to be associated with a 2 -fold increase in cancer-related mortality. ${ }^{20}$ Neuroblastoma cells with silenced lamin $\mathrm{A} / \mathrm{C}$ by hypermethylation display more aggressive behavior. ${ }^{21}$

Lamin B1 expression is considerably increased in hepatocellular carcinoma and is related to the tumor size, tumor stage and the number of nodules. Increased plasma lamin B1 levels can also be used to predict hepatocellular carcinoma in the early stage. ${ }^{22}$ In their study, Marshall et al. showed that lamin B1 could be a useful clinical marker in the colorectal cancers. ${ }^{23}$

The mRNA expressions of lamin A/C, lamin B1 and lamin $\mathrm{B}$ receptors were investigated in 115 breast cancer tissues and 30 breast tissues without cancer and increased lamin $\mathrm{A} / \mathrm{C}$ expression was found to be associated with early clinical stage and good prognosis. An increased lamin B1 expression was found to be associated with poor prognosis, and increased expression of the lamin B receptor was found to be associated with tumor grade and to be related directly to the Nottingham prognostic index. ${ }^{24}$

$\mathrm{Li}$ et al. conducted research into the patients with pancreatic cancer, and the findings showed an ex- 
cessive expression of lamin B1 associated with low-grade differentiation, distant metastases and poor prognosis. The suppression of lamin B expression through betulinic acid therapy has resulted in a decrease in the proliferation, invasion and tumorogenic capacity of pancreatic cancer cells. ${ }^{25}$

In the present study, the lamin B1 protein gene expression was found to be significantly lower when compared to the control group $(\mathrm{p}=0.001)$. When the prognostic characteristics of patients with ALL are compared with the lamin B1 protein gene expression, it was found to be significantly higher only in patients with a white blood cell count of between 50.000 and 100.000 , and those with T-ALL compared to patients with B-cell ALL ( $p=0.009$ and 0.004 , respectively). Lamin $\mathrm{A} / \mathrm{C}$ and $\mathrm{B} 2$ protein gene expression levels at the time of diagnosis were higher in the non-survivors than in survivors $(\mathrm{p}=$ 0.036 and $p=0.005$, respectively), and these results can be linked indirectly to poor prognosis.

Jansen et al. evaluated lamin protein gene expressions in the tissues of patients with nodular sclerosing Hodgkin lymphoma and reactive lymph nodes, and in contrast to our findings, they suggested that lamin-A positive cells were of a non-proliferative character and that a low lamin B2 expression, in particular, may be associated with nodular sclerosing Hodgkin lymphoma. ${ }^{26}$

It has been shown previously that in leukaemia and lymphoma, aberrant transcriptional silencing by $\mathrm{CpG}$ island promoter hypermethylation is an important mechanism underlying the loss of Lamin $\mathrm{A} / \mathrm{C}$ expression and is associated with a poor outcome in diffuse large B-cell lymphomas. ${ }^{27}$ The lack of Lamin A/C expression in malignant B- and T- lymphocytes may point to a blockade of the differentiation pathway in these cells. ${ }^{28}$

In a study on lamin $\mathrm{A} / \mathrm{C}$ expression in myeloid leukemias, Kaufman demonstrated an expression of lamin $\mathrm{A} / \mathrm{C}$ in acute myeloid leukemias, which is a finding that contradicts general belief. Kaufmann evaluated the relationship between lamin $\mathrm{A} / \mathrm{C}$ expression and diagnosis and prognosis but found no significant relationship. ${ }^{10}$

When the patients are evaluated according to their prognostic factors, lamin B1 protein gene expres- sion at the time of diagnosis was found to be significantly higher in patients with ALL and a white blood cell count of between 50.000 and 100.000/ $\mathrm{mm}^{3}$, and lamin B1 and B2 protein gene expressions were significantly higher in patients with hepatomegaly and splenomegaly $(p<0.05)$. Findings suggest that lamin B1 and B2 protein gene expressions are higher in patients with a greater tumor load, and are associated with poor prognosis.

The lamin $\mathrm{A} / \mathrm{C}, \mathrm{B} 1$ and $\mathrm{B} 2$ protein gene expressions were divided into two groups: lower and higher than the control group, and the effects of each expression level on overall survival were investigated. ALL patients with higher lamin B2 protein gene expressions had better survival outcomes, and the results were statistically significant $(\mathrm{p}<0.05)$. The three-year survival rate was $82.5 \%$ and the five-year survival rate was 75\% in ALL patients with a higher lamin B2 protein gene expression. The three- and five-year survival rates in ALL patients with a lower lamin B2 protein gene expression was $65 \%$. In contrast, the effects of lamin $\mathrm{A} / \mathrm{C}$ and lamin $\mathrm{B} 1$ protein gene expressions in ALL patients were not statistically significant $(\mathrm{p}>0.05)$.

In conclusion, a review of previous studies shows that lamin protein gene expression has mostly been studied in solid tumors. The study by Scot et al. conducted on hematological malignancies focused only on myeloid leukemia and showed only lamin A/C expression, and this finding was not associated with diagnosis or prognosis. To our knowledge, the present study is the first to be conducted in childhood ALLs. Lamin A/C and B2 protein gene expressions were higher (the difference was not statistically significant, $\mathrm{p}>0.05$ ) and the lamin $\mathrm{B} 1$ protein gene expression was significantly lower in the ALL group than in the control group $(\mathrm{p}=0.001)$. A significant decrease was observed in the lamin $\mathrm{A} / \mathrm{C}$ and $\mathrm{B} 2$ protein gene expressions after the administration of chemotherapy ( $\mathrm{p}=0.0001)$, while the decrease in lamin B1 protein gene expression was not significant. The significantly higher lamin $\mathrm{A} / \mathrm{C}$ and lamin $\mathrm{B} 2$ protein gene expressions in non-survivors during therapy in the present study suggests that lamin $\mathrm{A} / \mathrm{C}$ and lamin B2 proteins are associated with the prognosis. Due to the presence of a correlation between lamin B1 gene expression and various biochemical parameters, as well as the presence of a significant 
relationship with an elevated white blood cell count, hepatomegaly, splenomegaly and tumor load, lamin B1 protein could serve well as a biomarker in ALL.

In conclusion, lamin B1 protein gene expression could be used as a diagnostic marker, while lamin $\mathrm{A} / \mathrm{C}$ and lamin $\mathrm{B} 2$ protein gene expressions could be used as a prognostic marker in cases of acute childhood lymphoblastic leukemia. Accordingly, the authors consider further comprehensive multicenter studies with a larger cohort of patients would help clarify the current findings and establish the relationship of lamin proteins with diagnosis and prognosis.

\section{ACKNOWLEDGMENTS}

This work was supported by 'Cukurova University Research Projects Funding Unit' with Project number TF2013LTP34 (ID715).

\section{REFERENCES}

1. Rabin KR, Gramatges MM, Margolin JF, Poplack DG. Acute Lymphoblastic Leukemia. In Pizzo PA, Poplack DG, Eds. Principles and Practice of Pediatric Oncology, 7th ed. Philadelphia: Wolters Kluwer, 2016:463-497.

2. Goldman RD, Goldman AE, Shumaker DK. Nuclear lamins: building blocks of nuclear structure and function. Novartis Found Sym 264: 3-16, 2005.

3. Lin F, Worman HJ. Structural organization of the human gene encoding nuclear lamin A and nuclear lamin C. J Biol Chem 268: 16321-16326, 1993.

4. Machiels BM, Zorenc AH, Endert JM, et al. An alternative splicing product of the lamin A/C gene lacks exon 10. J Biol Chem 271: 9249-9253, 1996.

5. Lin F, Worman HJ. Structural organization of the humangene (LMNB1) encoding nuclear lamin B1. Genomics 27: 230-236, 1995.

6. Harborth J, Elbashir SM, Bechert K, et al. Identification of essential genes in cultured mammalian cells using small interfering RNAs. J Cell Sci 114: 4557-4565, 2001.

7. Broers JL, Machiels BM, Kuijpers HJ, et al. A- and B-type lamins are differentially expressed in normal human tissues. Histochem. Cell Bio 107: 505-517, 1997.

8. Foster CR, Przyborski SA, Wilson RG, Hutchison CJ. Lamins as cancer biomarkers. Biochem Soc Trans 38: 297-300, 2010.
9. Dittmer T, Mitseli T. The lamin protein family. Genome Biology 12: 222, 2011.

10. Kaufman SH. Expression of Nuclear Envelope Lamins A and C in Human Myeloid Leukemias. Cancer Research 52: $2847-$ 2853, 1992.

11. Davilla ML, Riviere I, Wang X, et al. Efficacy and toxicity management of 19-28z CART cell therapy in B cell acute lymphoblastic leukemia. Sci Transl Med 6: 224-225, 2014.

12. Scheure ME, Bondy ML, Gurney JG. Pathology and Molecular Diagnosis of Leukemias and Lymphomas. In: Margolin JF, Steubsr CP, Poplack DG, Eds. Principles and Practice of Pediatric Oncology, 6th ed. Philadelphia: Lippincott Wiliams\&Wilkins, 2011: 2-16.

13. Broers JL, Ramaekers FC, Bonne G, et al. Nuclear lamins: laminopathies and their role in prematureageing. Physiol 86: 967-1008, 2006.

14. Kaufmann SH, Mabry M, Jasti R, Shaper JH. Differential expression of nuclear envelope lamins $\mathrm{A}$ and $\mathrm{C}$ in human lung cancer cell lines. Cancer Res 51: 581-586, 1991.

15. Broers JL, Raymond $\mathrm{Y}$, Rot MK, et al. Nuclear A-type lamins are differentially expressed in human lung cancer subtypes. Am J Pathol 143: 211-220, 1993.

16. Moss SF, Krivosheyev V, de Souza A, et al. Decreased and aberrant nuclear lamin expression in gastrointestinal tract neoplasms. Gut 45: 723-729, 1999.

17. Tilli CM, Ramaekers FC, Broers JL, et al. Lamin expression in normal human skin, actinic keratosis, squamous cell carcinoma and basal cell carcinoma. Br J Dermatol 148: 102-109, 2003.

18. Broers JL, Ramaekers FC. The role of the nuclear lamina in cancer and apoptosis. Adv Exp Med Biol 773: 27-48, 2014.

19. Skvortsov S, Schafer G, Stasyk T, et al. Proteomics profiling of microdissected low- and high-grade prostate tumors identifies lamin a as a discriminatory biomarker. J Proteome Res 10: 259-268, 2011.

20. Willis ND, Cox TR, Rahman-Casans SF, et al. Lamin A/C is a risk biomarker in colorectal cancer. PLoS One 3: 2988, 2008.

21. Rauschert I, Aldunate F, Preussner J, et al. Promoter hypermethylation as a mechanism for Lamin A/C silencing in a subset of neuroblastoma cells. PLoS One 19: 12, 2017.

22. Sun S, Xu MZ, Poon RT, et al. Circulating Lamin B1 (LMNB1) biomarker detects early stages of liver cancer in patients. $J$ Proteome Res 9: 70-78, 2010.

23. Marshall KW, Mohr S, Khettabi FE, et al. A blood-based biomarker panel for stratifying current risk for colorectal cancer. Int J Cancer 126: 1177-1186, 2010.

24. Wazir U, Ahmed MH, Bridger JM, et al. The clinicopathological significance of lamin $\mathrm{A} / \mathrm{C}$, lamin $\mathrm{B}$ 1and lamin $\mathrm{B}$ receptor mRNAexpression in human breast cancer. Cell Mol Biol Let 18: 595-611, 2013 
25. Li L, Du $Y$, Kong $X$, et al. Lamin B1 is a novel therapeutic target of betulinic acid in pancreatic cancer. Clin Cancer Res 19: 4651-4661, 2013.

26. Jansen MP, Machiels BM, Hopman AH, et al. Comparison of $\mathrm{A}$ and $\mathrm{B}$-type lamin expression in reactive lymph nodes and nodular sclerosing Hodgkin's disease. Histopathology 31 : 304-312, 1997.

27. Aglero R, Setien F, Espada J, et al. Inactivation of the lamin A/Cgene by CpG island promoter hypermethylation in hematologic malignancies, and its association with poor survival in nodal diffuse large B-cell lymphoma. J Clin Oncol 23: 3940$3947,2005$.

28. Bell ES, Lammerding J. Causes and consequences of nuclear envelope alterations in tumour progression. Eur $\mathrm{J}$ Cell Biol 95: 449-464, 2016.

\section{Correspondence:}

Dr. Ayse OZKAN

Cukurova Universitesi, Tip Fakultesi

Pediatrik Onkoloji ve Pediatrik Kemik lligi Transplantasyon

Ünitesi

01250 Balcali,

ADANA / TURKEY

Tel: (+90-322) 4559000 / 4124

e-mail: drayseozkan79@yahoo.com.tr 